Language and Language Teaching Journal http://e-journal.usd.ac.id/index.php/LLT Sanata Dharma University, Yogyakarta, Indonesia

\title{
Incorporating Memes and Instagram to Enhance Student's Participation
}

\author{
Agnes Dian Purnama \\ State University of Malang, East Java \\ nezz.dian15@gmail.com \\ DOI: doi.org/10.24071/1lt.2017a.20.01.01
}

\begin{abstract}
Today's teaching and learning faces more challenges as technology keeps on updating itself. Teachers are expected to adopt as many as possible technology products to promote students' engagement in classroom activity. Utilizing technology products may help teachers to decrease students' boredom inside classroom since it proposes a new kind of activity. The main purpose is to create an enjoyable teaching and learning environment as well as to trigger students to be creative. By highlighting youths' characteristics that tend to be visual and addicted to rapid information, memes and Instagram may be used as one of the strategies to develop an innovative teaching and learning process.
\end{abstract}

Keywords: memes, Instagram, language learning

\section{Introduction}

Taken as an inevitable truth, teaching and learning process nowadays is inseparable from the use of technology no matter how big or small it is. For example, when we ask our students to submit their work, almost all of them prefer to submit it via e-mail, Blackberry Messenger or even WhatsApp Group rather than using traditional style of paper-based work. That particular activity has been a major hit since the last two applications are up-to-date. Blackberry Messenger and WhatsApp are equipped with an ability to receive and send documents and still serve their basic function as chat applications: sending and retrieving messages.

When we go back twelve or thirteen years earlier, it was acceptable among us to be unequipped with technology, such as mobile phone latest product. We were certainly fine if we did not acquire any contact with technology for days. But now, real life truth speaks differently. Almost all of us experience similar phenomenon. We, teachers, as well as our students are bound to internet and mobile phone. Like it or not, the one who does not fluently speak the same "language" like us, would certainly be alienated.

Early in 2000s, Prensky came upon a new term of Digital Natives and Digital Immigrants. Digital Natives are those who perform and rely almost all of their activities on technology. Our students are by all means called as Digital Natives. They speak and breathe technology as daily intake. According to Prensky, they are "...all "native speakers" of the digital language of computers, video games and the Internet." (2001:1)

"Digital Immigrants learn - like all immigrants, some better than others - to adapt to their environment, they always retain, to some degree, their "accent," that 
is, their foot in the past. The "digital immigrant accent" can be seen in such things as turning to the Internet for information second rather than first, or in reading the manual for a program rather than assuming that the program itself will teach us to use it" (Prensky, 2001: 2).

"The differences between Digital Natives and Digital Immigrants lie upon their learning traits and preferences" (Prensky, 2001: 2-3). Digital Natives are used to receive information really fast. They like to parallel process and multitask. They prefer their graphics before their text rather than the opposite. They prefer random access (like hypertext). They function best when networked. They thrive on instant gratification and frequent rewards. They prefer games to "serious" work.

Digital Immigrant teachers tend to teach - slowly, step-by-step, one thing at a time, individually, and above all, seriously. Digital Immigrants do not believe their students can learn successfully while watching TV or listening to music, because they (the Immigrants) cannot. Digital Immigrants think that learning cannot (or should not) be fun.

Based on the previous explanation, an integrated activity of memes creation and Instagram posting is proposed as an alternative strategy that yields creativity and innovation for teaching and learning process. Memes are dense. It has an attractive packaging (for example: eye catchy image wrapped with catchy text) which is an additional value for our students; the Digital Natives. Moreover, it can be distributed among people and posted online easily.

\section{Infecting the Mind: Memes Creation}

Taking memes' original definition into perspective, researcher would like to develop a new strategy to enhance students' classroom participation and the teaching and learning process of English. "Examples of memes are tunes, ideas, catch-phrases, clothes fashions and ways of making pots or of building arches. Just as genes propagate themselves in the gene pool by leaping from body to body via sperms or eggs, so memes propagate themselves in the meme pool by leaping from brain to brain via a process which, in the broad sense, can be called imitation" (Dawkins, 2006: 192).

Researcher assumes that since memes embody longevity, fecundity, and copying-fidelity traits, thus it will be easier to be applied into classroom that is fully loaded by Digital Natives. Furthermore, Brodie says that "A meme is a unit of information in a mind whose existence influences events such that more copies of it get created in other minds." (2009: 11) When some people understand memes merely as catchy images with catchy texts, do not forget that those are only 'vehicles'. A cart carries information. Anything that can be copied and spread between brains, are definitely memes.

"As long as that information can be copied by a process we may broadly call 'imitation', then it counts as a meme" (Blackmore, 1999: 66).

\section{Instagramming}

Utilizing social media into teaching and learning process is not something uncommon. Previous studies have been conducted to shed light on the need of 
facilitating technology more into our practice as teacher. (Astuti, 2016; Blattner \& Fiori, 2009; Grewal \& Harris, 2009; Guikema \& Williams, 2014; Guikema \& Menke, 2014; Hattem, 2014; Kalasi, 2014; Lomicka \& Lord, 2012 \& 2014; Yunus et.al, 2012) Thus, choosing the most suitable social media application will be subject to classroom teacher's judgment.

Let us not forget also that each social media application certainly has its own strengths and weaknesses. In order to be able to choose the most suitable application, teachers should pay close attention to their students' characteristics. Researcher has her own consideration by choosing Instagram as a partnering social media for memes creation activity.

First, Instagramming is an activity that most youth, the Digital Natives, would certainly fall into. Second, it gives a diverse range of any images starting from beautiful scenery up to beauty products. Third, Instagram posts tend to have minimum texts yet are quite rich in image presentation. Last, it is easily shared and distributed among people.

\section{Method}

The participants of the study are 23 EFL students of Health College in the regency area of Malang. There are 4 male students and 19 female students. They are second semester students of health diploma degree and all of them are taking English as a compulsory subject. None of the participants are native speakers of English. They speak Bahasa Indonesia as their first language.

Table 1. Participant Information

\begin{tabular}{lll}
\hline & Male & Female \\
\hline Number of participants & 4 & 19 \\
Age (range) & $20-21$ years old & $19-21$ years old \\
Length of English exposure & $6-12$ years & 6-12 years \\
\hline
\end{tabular}

The instruments used in this research are observation and questionnaires. The observation was carried out using memes creation and Instagram account, whereas the questionnaires were distributed in the beginning and at the end of the study.

Prior the study, participants were given a preliminary questionnaire (Questionnaire I) composed of questions about English and social media.

Table 2. Questionnaire I

\begin{tabular}{ll}
\hline & Questions \\
\hline 1. & What do you think about English? \\
2. & Do you know social media sites? Please, give examples. \\
3. & Do you have any social media account? How many? What are they? \\
4. & Do you know memes? \\
5. & What is your opinion about memes? Do you like it? \\
\hline
\end{tabular}

Participants are divided into groups. It consists of 11 groups. The number of group member varies from 1 person to 3 persons (mixed sexes). Each group is asked to develop one meme based on the given topics that they have already 
received during English classes. There are two topics: symptoms and caring for elderly. Each group is given the same length of time of meme submissions (2 weeks). Each group is assigned to upload or post their meme(s) creation in the appointed Instagram account. Posted group memes are collected into a single Instagram account (researcher's account:@memes_project). Participants are asked to answer questions which are enlisted in post study questionnaire (Questionnaire II).

Table 3. Questionnaire II

\begin{tabular}{ll}
\hline & Questions \\
\hline 2. & What is your opinion about using memes inside classroom? \\
Does meme help you to understand your English materials (symptoms and \\
caring for elderly) better? \\
4. $\quad \begin{array}{l}\text { Is it enjoyable to make memes and post it in Instagram? } \\
\text { Would you like to have this kind of classroom activity for another topic? Or } \\
\text { on what kind of English lesson? }\end{array}$ \\
$\begin{array}{l}\text { Do you agree/ disagree if the teaching of English is combined with social } \\
\text { media (Instagram) application? Why? }\end{array}$ \\
Do you have any other preference of social media application usage inside \\
classroom? What is it?
\end{tabular}

There are 14 memes collected by the researcher. All the written texts on the memes are analyzed. The following components are taken into account: image sorting, written text, content/ message (appropriateness between image, written text, and topics). Collected memes are divided into 2 parts. The partition used is based on the following topics: symptoms and caring for elderly. A deeper explanation of component analysis will be described further in finding and discussion section.

\section{Findings and Discussion}

Throughout the process of study and observation, researcher has collected 14 memes that are divided into two topics: symptoms and caring for elderly. Topics are authorized by English lecturer of the participants. It is based on the participants' college syllabus and material. At preliminary meeting with students, researcher asks students to create memes as a product of their English class. Participants are expected to meet "correct" memes creation. Correct definition carries further explanation that participants' image choice fit the embodied text as well as the content. Later on, this product will serve as a checking tool. It observes students' ability of understanding today's topic well.

To prevent any emerging sensitive issue, such as bullying, bashing, or body shaming, researcher asks participants to use their own images, movie scenes or cartoons. It is also recommended for participants to engage themselves more on technology by using any picture editing tool that they prefer. Below is the description of each submitted meme based on the topics. 


\section{First Topic: Symptoms}

For this topic, researcher collects all memes made by participants and posts them using an Instagram account @memes_project. To make it simpler, either for researcher or group of participants, there is an agreement that both parties should follow one another so that both parties would be able to evaluate each meme that has been made. From a total number of 11 groups of participants, only 8 groups that complete the memes submission requests.
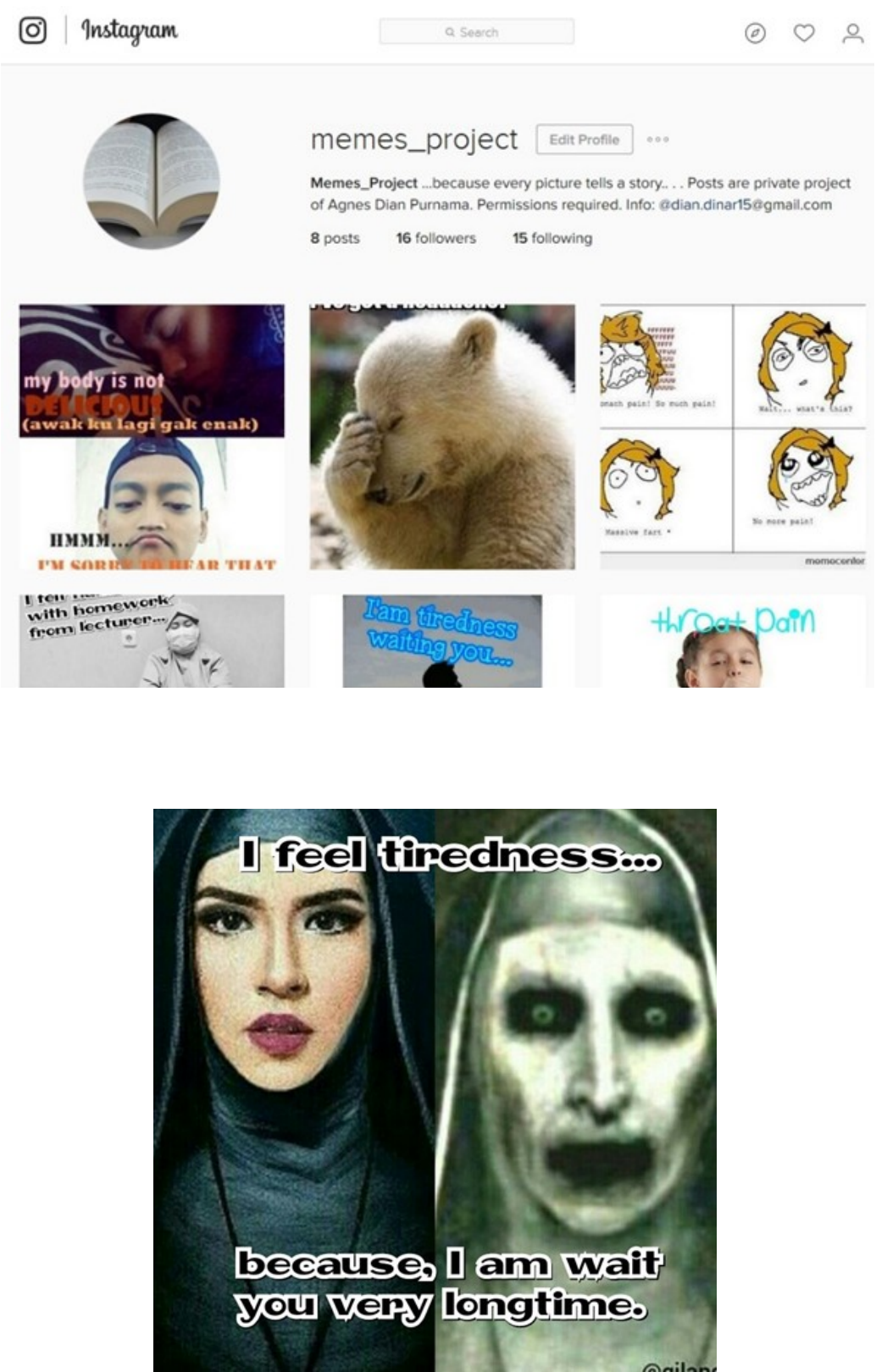

Figure 1. Instagram look of @memes_project 


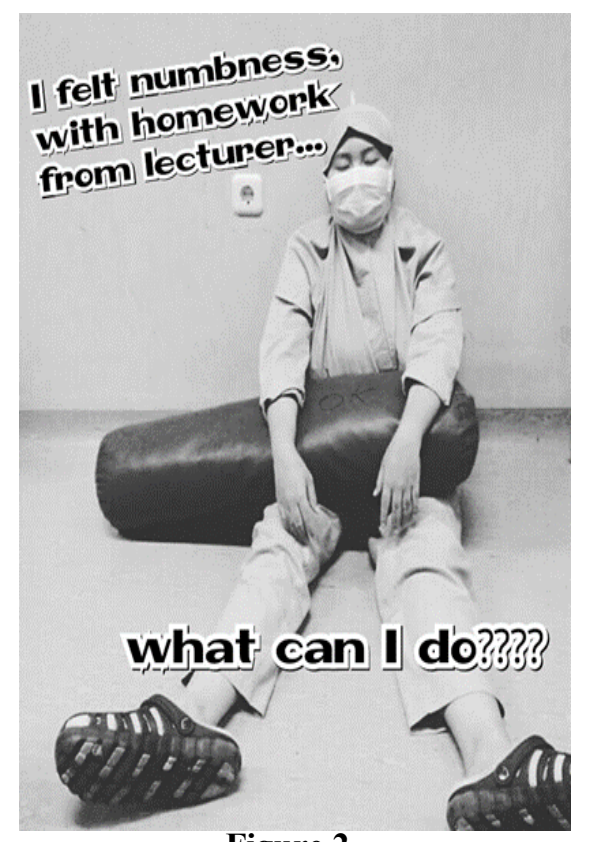

Figure 2

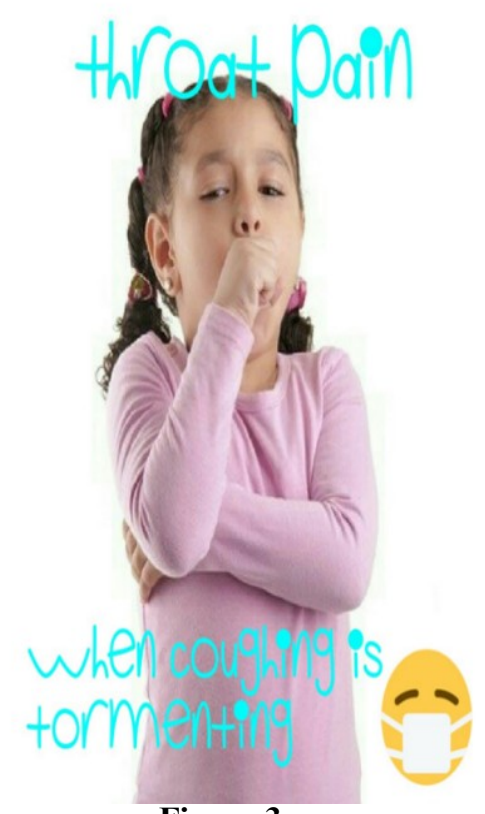

Figure 3
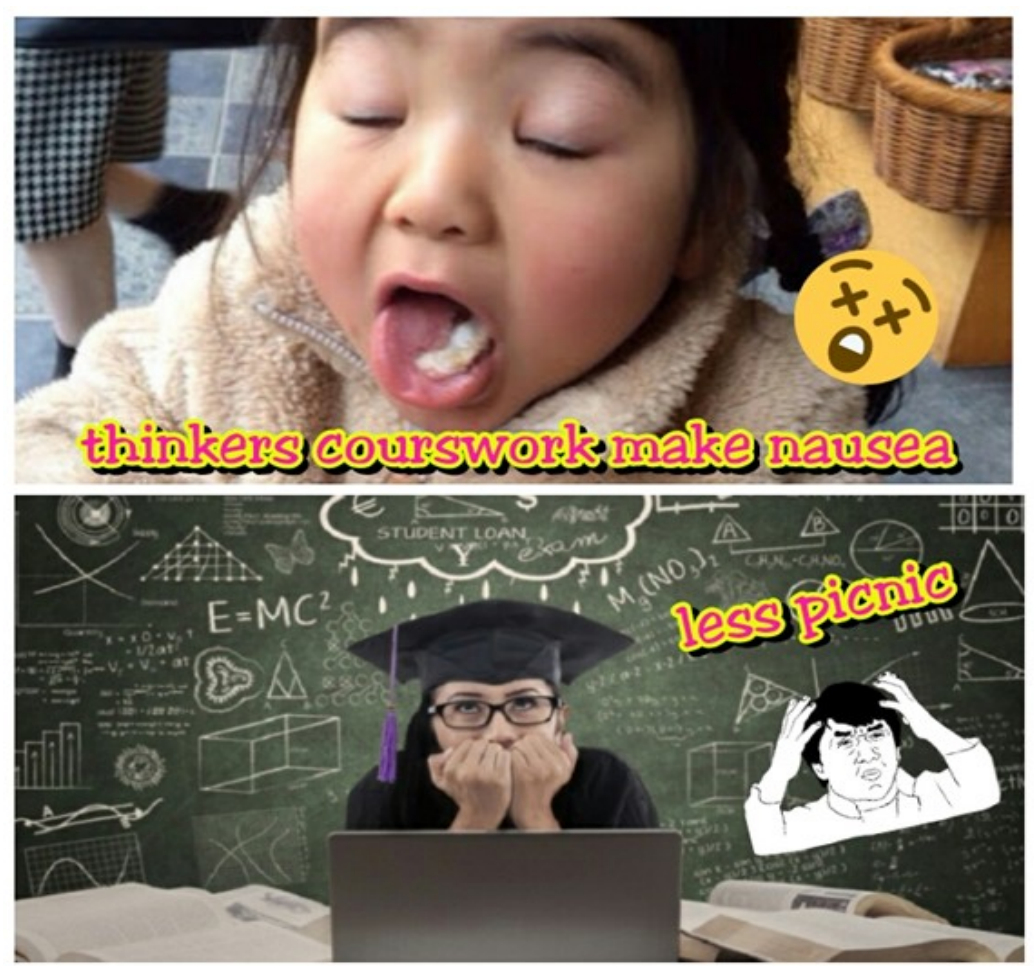

Figure 4

From Figures 1-4, we can see that participants meet the criteria of choosing the appropriate images, text and also content (symptom topic). At the moment of analyzing participants' memes, researcher disobeys grammatical rules and writing system as long as the memes made are 'correct'. An exception is shown by figure 3 which is perfectly apt the condition of correct grammar. 


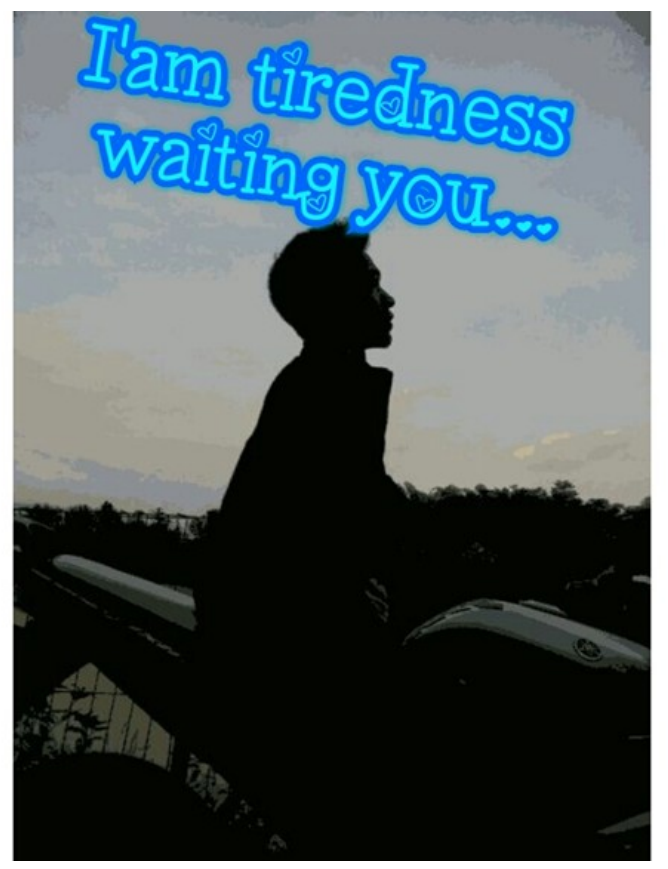

Figure 5

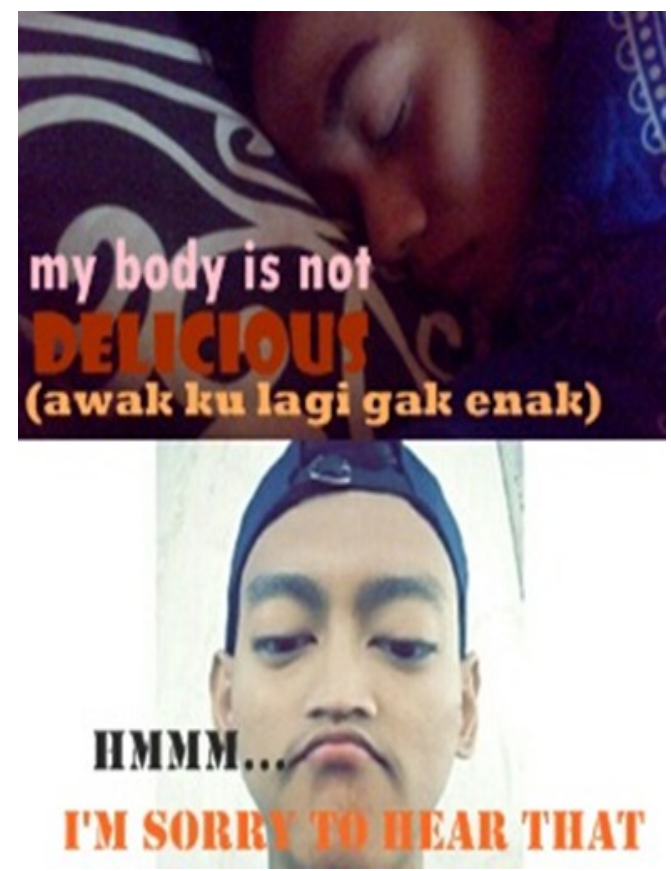

Figure 6

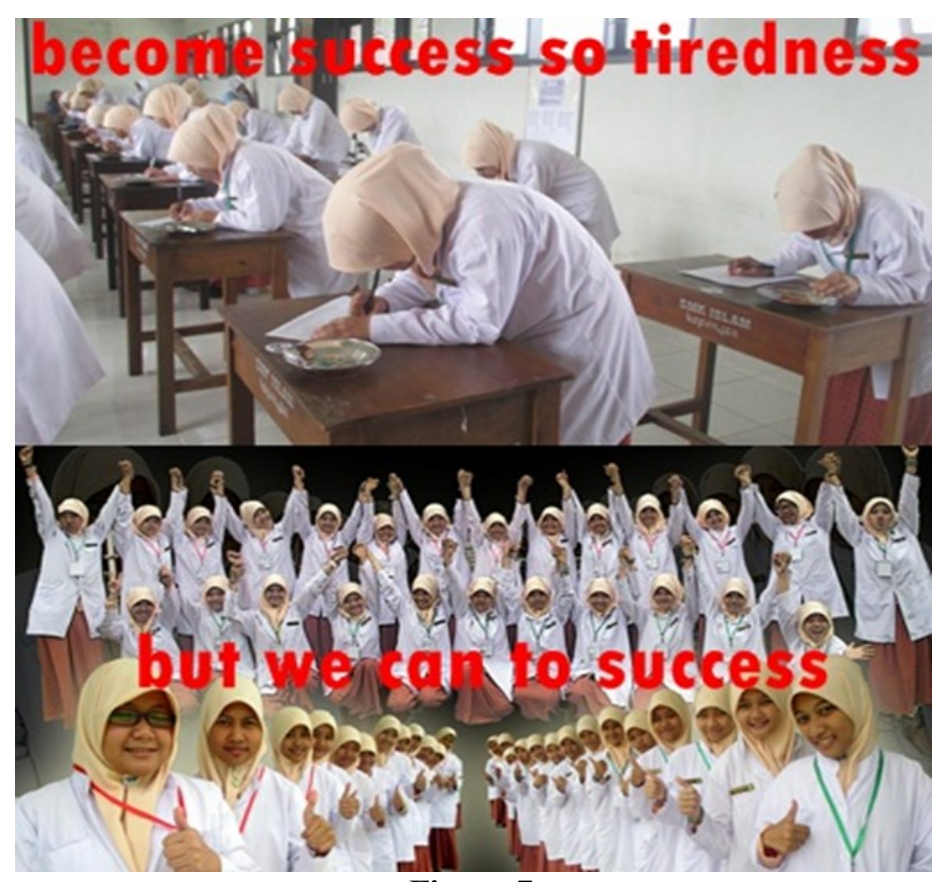

Figure 7

Figure 5 and 7 are described as memes that are less satisfactory fulfilling the adjacency of 'correct' memes. The idea presented by participants is to match the expression of tiredness with the chosen images. Figure 5 is best taken as an example of youth's love life. Apparently, the participants want to describe the unrequited love expression using 'tiredness' word. Meanwhile, figure 7 tries to bring on Indonesia's famous proverb of "Berakit - rakit ke hulu, berenang - 
renang ke tepian. Bersakit - sakit dahulu, bersenang - senang kemudian." Or in English, it is commonly known as "No pain, no gain."

In figure 6, participants apply direct translation technique from L1 to L2 without using any prior knowledge about L2. Participants translated common expression of "Tidak enak badan" in Bahasa Indonesia into "My body is not delicious." The word 'enak' is directly translated into 'delicious'. The word 'enak' in Bahasa Indonesia has two meanings. The first meaning is similar to 'tasty or delicious'. It is usually applied for expressing our judgment about certain dish or meal. The second meaning of 'enak' can be used also for expressing feeling; 'enak' = 'comfortable'. Participants' lack of understanding about homonymy in L1 and language expressions in L2 lead into burst of laughers from other students by the time this figure is posted on Instagram.

The last figure in this section, figure 8, sparks an ambiguity of meaning. Participants use "sakit hati" expression in Bahasa Indonesia and make a direct translation into English as "sickness". Sickness in this meme grasps a different meaning than its' original meaning of being ill or the resulted condition of vomiting.

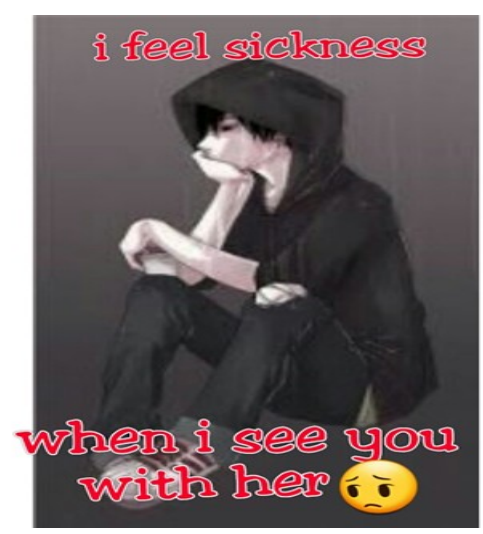

Figure 8

Second topic: caring for elderly

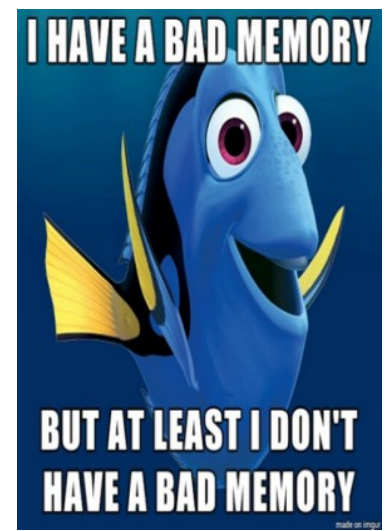

Figure 9

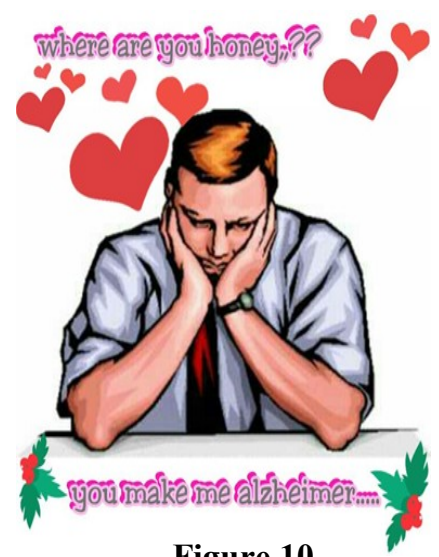

Figure 10

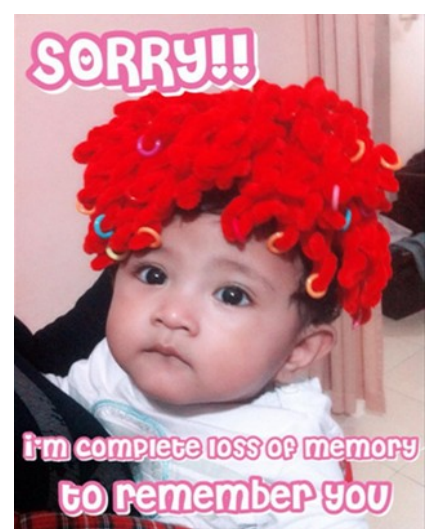

Figure 11 
Due to some reasons, only three groups of participants took part in creating memes in caring for elderly topic. At this period, three groups make a direct posting on Instagram without the help of @memes_project account. A further analysis is conducted similar to previous topic. Researcher evaluates the appropriateness of chosen images, written text and also the memes meaning or content.

Next, let us have a closer look on figure 9. Researcher argues that this meme belongs to 'correct' memes. The meme that contains a picture of a smiling fish may not directly explain the relation between a smile and bad memory. But, it describes that particular fish characteristic perfectly. The fish name is Dory. It is a cartoon character that can be found in Finding Nemo and Finding Dory movies made by Pixar. Participants bring an issue about Dory's character that suffers from short term memory into memes.

Figure 10 and figure 11 highlight common condition found among elderly people, Alzheimer and complete loss of memory. Although it may not be completely correct in grammar or word choice, it still meets the criteria of 'correct' memes.

The rest 3 memes out of 14 made memes are eliminated due to originality issue and out of requested topics. Thus, by far, participants are successful in creating 11 memes based on the topics provided although some groups did not participate thoroughly until the end of the study.

To make it accessible for participants or public query, researcher creates hashtags (\#) based on the topics. For the first topic, researcher uses \#memesproject1 and \#symptoms as hashtags. Meanwhile, the second topic falls into \#memesproject2 and \#caringforelderly hashtags.

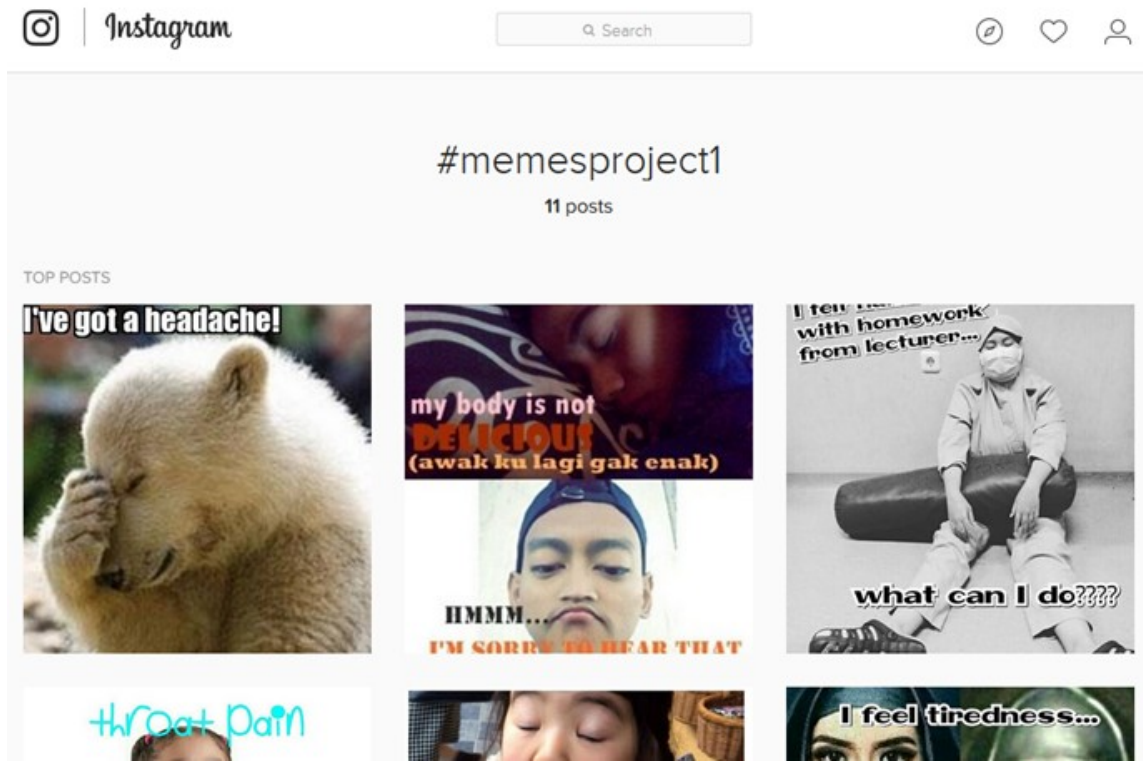

Figure 12 a 
LLT, ISSN 1410-7201, Vol. 20, No. 1, April 2017

(0) Instagram
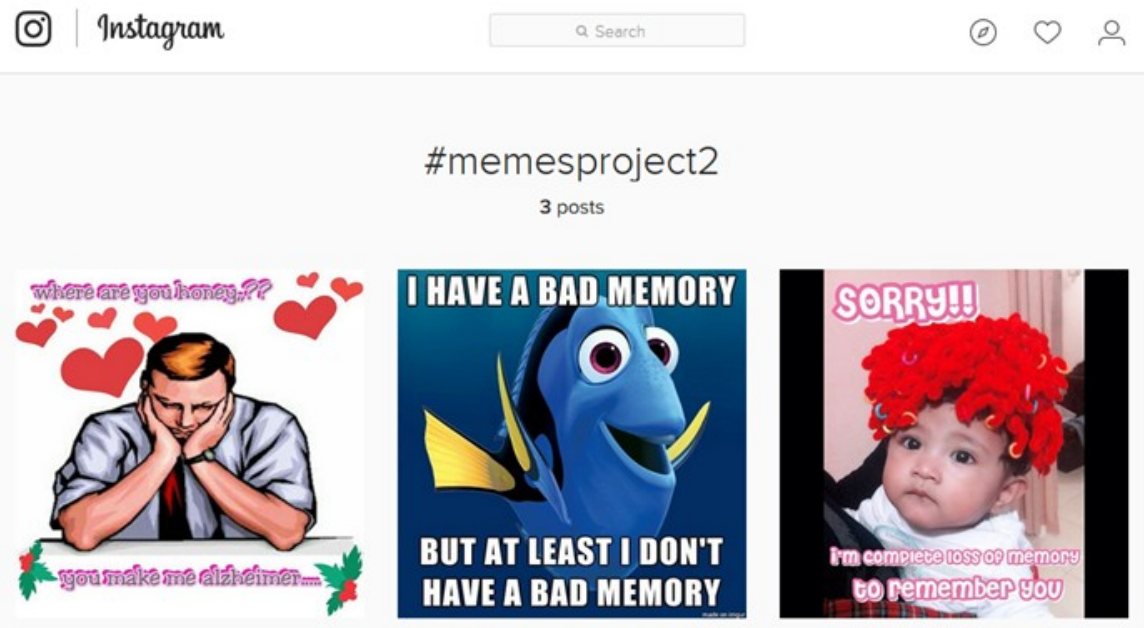

HAVE A BAD MEMORY

(a) $0 \stackrel{\circ}{\circ}$

Figure 12 b

The following figures are self-made posts which are conducted privately by participants. Here, participants receive direct feedback for their memes creation from non-study participants. It can be seen from the amount of likes that participants get.

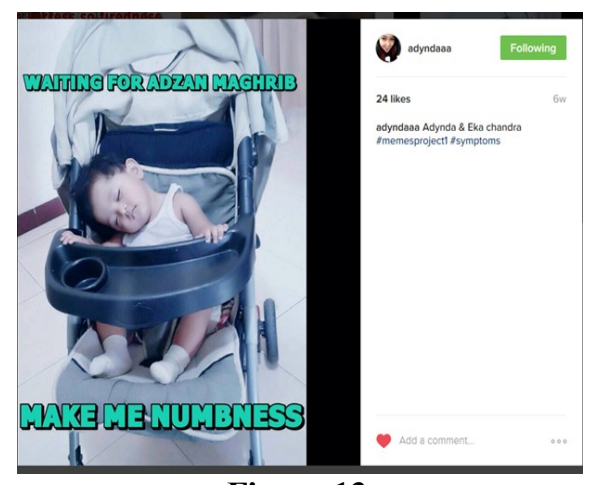

Figure 13

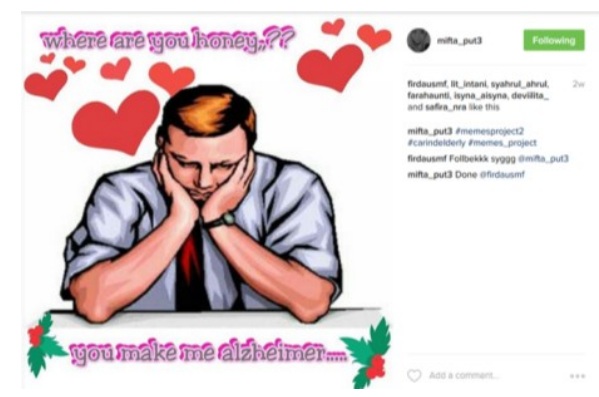

Figure 15

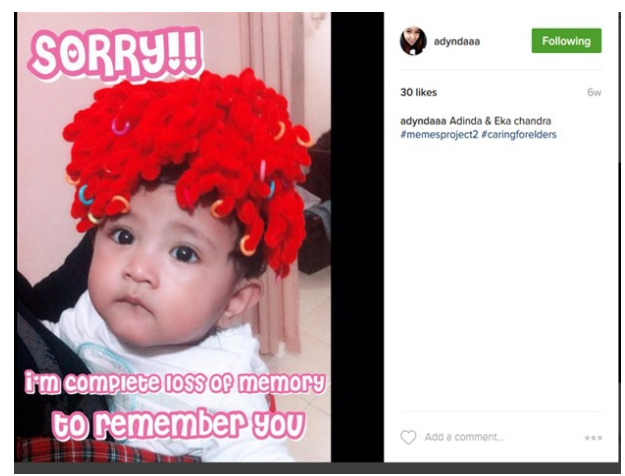

Figure 14

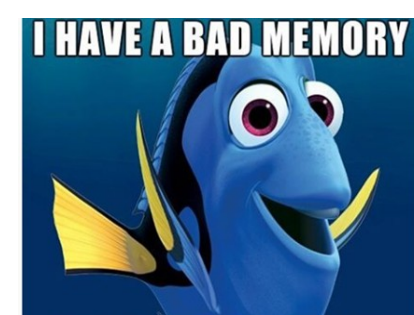

BUT AT LEST I DOW' BAVE A BAD MEMORY

Figure 16 


\section{Questionnaire}

\section{Questionnaire I}

Question 1. What do you think about English? From the total number of 23 participants, 13 participants think that English is difficult. Three participants have an opinion that English classroom is fun but learning English is hard. Only three participants truly consider learning English fun.

Question 2. Do you know any social media sites? Please, give examples. Only one participant does not know about social media sites. Twenty participants are able to give example about social media sites.

Question 3. Do you have any social media accounts? How many? What are they? On average, 22 participants own at least 2 social media accounts and most of them have Facebook account. Only one participant does not have any social media account.

Question 4. Do you know memes? All of participants are familiar with memes.

Question 5. What is your opinion about memes? Do you like it? All of participants like memes because they are funny.

\section{Questionnaire II}

Question 1. What is your opinion on using memes inside classroom? All of participants agree upon memes integration for language learning and teaching process.

Question 2. Does meme help you to understand your English materials (symptoms and caring for elderly) better? One participant feels that memes fail to help him to understand English materials (symptoms and caring for elderly topics) better. Three participants strongly agree that memes help them to learn English better although it is not commonly used.

Question 3. Is it enjoyable to make memes and post them on Instagram? Participants do not have any objection in creating memes. They say, it is an enjoyable activity.

Question 4. Would you like to have this kind of classroom activity for another topic? Or on what kind of English lesson? Participants only answered the first question that they would prefer to have another experience utilizing memes as a learning tool without describing any further references of kind of English lesson that they wish for.

Question 5. Do you agree or disagree if the teaching of English is combined with social media (Instagram) application? Why? All participants state their agreement on using a social media integrated into the English learning process.

Question 6. Do you have any other preferences of social media application usage inside classroom? What is it? All participants do not have any suggestions for other social media application to be applied inside classroom.

Question 7. What is your suggestion for English classroom activity? This question is not counted as questionnaire result because most participants have misconception about the meaning of the question. 


\section{Conclusion}

This study seeks an opportunity to gain a wider yet meaningful engagement of technology and language learning, especially by incorporating images, written text, and specialized topics into a social media application posting (memes and Instagram). The result, as it is expected, students prefer this kind of activity better than previous activity that they have encountered inside classroom. There are advantages in utilizing memes in order to be creative and innovative in language teaching. The first advantage is that memes creation proposes an eye catching learning process which will be easily adopted by students. The second advantage is memes creation is possible. Smartphones and any mobile image editing application are not uncommon for students. The third advantage is students gain a better understanding on English class' topics and English in general using a simple and enjoyable technique.

Technology rapid movement is arguably pervasive. Thus, by creating an enjoyable yet fun mixed form of language learning activity and technology, researcher believes that students would benefit more in the long run. At this point, researcher has the same opinion as Dörnyei (2001: 51) that "...the most farreaching consequences in motivating L2 learners can be achieved by promoting positive language-related values and attitudes." As Dörnyei explained, "actual process of learning the target language - intrinsic value; target language itself and its speakers - integrative value; consequences and benefits of having learnt the target language - instrumental value"

Here, the researcher argues that memes creation is by far the current evidence that supports those three values well. Memes, at its basic meaning, is an idea which is shared among brains. It is about how we influence others using our own idea by taking advantages through appealing packaging, catchy phrases or tunes. (Brodie: 2009) When students feel relaxed, they would not feel that learning English is an obligation to pass a semester. Our students nowadays are marked with their high sensitivity to something hype and current. Meme is one of it since it is quite accessible through handy mobile applications and smart phones, the latest items that our students could not live without. To be sure, this is the moment when intrinsic values are added.

Integrative value takes place at the moment students make a group collaboration for creating memes. They communicate between one another to come up with 'an ideal meme' which is made through discussion. When students enjoy memes creation, post it on Instagram, and get likes (the $\bullet$ button), it is indirectly stated that their social position is lifted up as it is stated by Dörnyei (2001: 56) instrumental value.

In spite of the results presented, further observation and research will be needed to see whether creating memes has a significant contribution to students' proficiency level of English since memes creation requires high order of thinking and not all participants are able to do it correctly. Future studies that involve memes creation as well as social media platform are expected to highlight the opportunity of developing this kind of strategy. It is suggested that future researchers use more than one social media applications to get a wider attention and to investigate its effect to students' language learning development. 


\section{References}

Andrews, R. \& Smith, A. (2011). Developing writers: Teaching and learning in the digital age. New York: Open University Press.

Astuti, S.P. (2016). Exploring motivational strategies of successful teachers. TEFLIN Journal, 27 (1), 1-22.

Blackmore, S. (1999). The meme machine. Oxford: Oxford University Press.

Blattner, G., \& Fiori, M. (2009). Facebook in the language classroom: Promises and possibilities, International Journal of Instructional Technology and Distance Learning, 6 (1), 17-28. Retrieved from http://itdl.org/journal/jan_09/article02.htm

Brodie, R. (2009). Virus of the Mind: The new science of the meme. London: Hay House.

Dawkins, R. (2006). The selfish gene: 30th anniversary edition. Oxford: Oxford University Press.

Dolean, D.D. (2015). The effects of teaching songs during foreign language classes on students' foreign language anxiety. Language Teaching Research, $1-16$.

Dornyei, Z. (2001). Motivational strategies in the language classroom (5th ed). Cambridge: Cambridge University Press.

Grewal, S. K. \& Harris, L. (2009). Learning virtually or virtually distracted? The impact of emerging internet technologies on pedagogical practice. In $\mathrm{N}$. Panteli. (Ed.), Virtual Social Networks. Mediated, Massive and Multiplayer Sites (pp. 18-35) London: Palgrave Macmillan.

Guikema, J. P. \& Williams, L. (2014). Digital literacies from multiple perspectives. In J. P. Guikema \& L. Williams (Eds.), Digital literacies in foreign and second language education. CALICO Monograph Series, Volume 12 (pp. 1-7). Texas: Computer Assisted Language Instruction Consortium (CALICO) Texas State University.

Guikema, J. P.\& Menke. M. R. (2014). Preparing future foreign teachers: The role of digital literacies. In J. P. Guikema \& L. Williams (Eds.), Digital literacies in foreign and second language education. CALICO Monograph Series, Volume 12 (pp. 265-285). Texas: Computer Assisted Language Instruction Consortium (CALICO) Texas State University.

Hattem, D. (2014). Microblogging activities: Language play and tool transformation. Language Learning and Technology, 18 (2), 151-174. Retrieved from http://ltt.msu.edu/issues/june2014/hattem.pdf

Jenkins, H. (2006). Convergence culture: Where old and new media collide. New York: New York University Press.

Jenkins, H., Ford, S. \& Green, J. (2013). Spreadable media: creating value and meaning in a networked culture. New York: New York University Press.

Kalasi, R. (2014). The impact of social networking on new age teaching and learning: An overview. Journal of Education \& Social Policy, 1 (1).

Kavaliauskiené, G. \& Ashkinazi, V. (2014). Social networking systems in teaching/ learning English for specific purposes. English for Specific Purposes World, 42(15). Retrieved from www.esp-world.info 
Lankshear, C., \& Knobel, M. (2011). New literacies: Everyday practices and classroom learning (3rd ed.). New York: Open University Press.

Lankshear, C. \& Knobel, M. (2011). New literacies: Everyday practices and social learning. 3rd Edition. New York: Open University Press.

Linaschke, J. (2011). Getting the most from Instagram. Berkeley: Peachpit Press

Lomicka, L., \& Lord, G. (2012) 'A tale of tweets: Analyzing microblogging among language learners', System, 40, 48-63.

Lomicka, L., \& Lord, G. (2016). Social networking and language learning. The Routledge Handbook of Language Learning and Technology, 255.

Prensky, M. (2001a). Digital natives, digital immigrants. On the Horizon, 9(5). Retrieved from http://www.marcprensky.com/writing/Prensky\%20\%20Digital\%20Natives, \% 20Digital\%20Immigrants\%20-\%20Part1.pdf

Prensky, M. (2001b). Digital natives, digital immigrants: Do they really think different? On the Horizon, 9(6), 1-6. Retrieved from http://www.marcprensky.com/writing/Prensky\%20\%20Digital\%20Natives, \% 20Digital\%20Immigrants\%20-\%20Part2.pdf

Prensky, M. (2010). Teaching digital natives: Partnering for real learning (1st ed.). Thousand Oaks, CA: Corwin Press.

Shifman, L. (2014). Memes in digital culture. Massachusetts: MIT Press.

Tuned-Awe, B. (2015). Relevance of online social networking in the teaching of English as a second language in Nigeria universities. European Scientific Journal February Edition, 11 (4), 252-262.

Watkins, S. C. (2009). The young and the digital: What the migration to socialnetwork sites, games, and anytime, anywhere media means for our future. Boston: Beacon Press.

Wendt, B. (2014). The allure of the selfie: Instagram and the new self-portrait. Amsterdam: Institute of Network Cultures. Retrieved from http://www.networkedcultures.org/publications

Yunus, M. Md., Salehi, H., \& Chenzi, C. (2012). Integrating social networking tools into ESL writing classroom strengths and weaknesses. English Language Teaching, 5 (8), 42-48. Retrieved from www.ccsnet.org/elt 